\title{
PENTINGNYA PENDIDIKAN ANAK USIA DINI AGAR DAPAT TUMBUH DAN BERKEMBANG SEBAGAI GENERASI BANGSA HARAPAN DI MASA DEPAN
}

\author{
I KETUT TANU \\ Institut Hindu Dharma Negeri Denpasar \\ Email: ketuttanu@gmail.com
}

\begin{abstract}
Early childhood education for children of pre-school age (3-6 years) is important, because at this age is a period of forming the foundations of the human personality, the ability to think, intelligence, skills and self-reliance and social skills in accordance with the mandate education law.

Basically the child's world is a world of fundamental human progress toward a more perfect human adult. It has been realized that the generation is the next generation that needs to be nurtured from an early age, thus fostering early is the responsibility of families, neighborhoods and communities. Thus fostering pre-school age children, especially the role of the family is crucial development.

Early childhood is the golden period (golden age) for the development of the child to the educational process. This period is the years of valuable for a child to recognize different kinds of facts on the environment as a stimulus to the development of personality, psychomotor, cognitive and sosialnya.Untuk it for early childhood education in the form of stimuli (stimulation) from the immediate environment is indispensable for optimizing the child's ability.
\end{abstract}

\section{PENDAHULUAN}

Sebagian besar para ahli berpendapat baahwa anak adalah titipan tuhan yang harus dijaga dan dididik agar menjadi manusia yang berguna dan tidak menyusahkanya. Akan tetapi para ahli pendidikan berpendapat bahwa anak mempunyai hak dan kesempatan untuk berkembang sesuai potensinya terutama dalam bidang pendidikan (UU NO.20/2003). Setiap anak dilahirkan bersamaan dengan potensipotensi yang dimilikinya. Tak ada satu pun yang luput dari pengawasan dan Kepedulian-Nya. Sebab merupakan tugas orang tua dan guru untuk dapat menemukan potensinya tersebut.

Syaratnya adalah penerimaan yang utuh terhadap keadaan anak itu.Dalam bidang pendidikan seorang anak dari lahir memerlukan pelayanan yang tepat dalam pemenuhan kebutuhan anak terhadap pendidikan yang disertai dengan pemahaman mengenai karakteristik anak sesuai pertumbuhan dan perkembangannya dalam menyesuaikan proses belajar bagi anak dengan usianya, kebutuhan akan sarana maupun prasarana, dan kondisi masingmasing anak, baik secara intelektual, emosional dan perkembangan sosial.

Masa usia dini merupakan periode emas (golden age) bagi perkembangan anak untuk memperoleh proses pendidikan.Sebab pada periode ini adalah tahun-tahun berharga bagi seorang anak untuk mengenali berbagai macam fakta di lingkungannya sebagai stimulans terhadap perkembangan kepribadian, psikomotor, kognitif maupun sosialnya.

Untuk itu pendidikan anak usia dini dalam bentuk pemberian rangsanganrangsangan (stimulasi) oleh oang tua, guru dan lingkungan terdekat sangat diperlukan untuk mengoptimalkan kemampuan dan perkebangan anak.Agar tumbuh dan berkembang sesuai dengan fasenya 


\section{PEMBAHASAN}

\section{Pendidikan Anak Usia Dini (PAUD)}

Pendidikan adalah usaha sadar dan terencana untuk mewujudkan suasana belajar dan proses pembelajaran agar peserta didik secara aktif mengembangkan potensi dirinya untuk memiliki kekuatan spiritual keagamaan, pengendalian diri, kepribadian, kecerdasan, akhlak mulia, serta keterampilan yang diperlukan dirinya dan masyarakat. Pendidikan meliputi pengajaran keahlian khusus, dan juga sesuatu yang tidak dapat dilihat tetapi lebih mendalam yaitu pemberian pengetahuan, pertimbangan dan kebijaksanaan. Salah satu dasar utama pendidikan adalah untuk mengajar kebudayaan melewati generasi.

Pendidikan anak usia dini (PAUD) adalah suatu upaya pembinaan yang ditujukan bagi anak sejak lahir sampai dengan usia enam tahun yang dilakukan melalui pemberian rangsangan pendidikan untuk membantu pertumbuhan dan perkembangan jasmani dan rohani agar anak memiliki kesiapan dalam memasuki pendidikan lebih lanjut. Pendidikan anak usia dini mulai lahir sampai baligh (kalau perempuan ditandai menstruasi sedangkan laki-laki sudah mimpi sampai mengeluarkan air mani) adalah tanggung jawab sepenuhnya orang tua.

Menurut Undang-undang Nomor 20 Tahun 2003 tentang Sistem Pendidikan Nasional pada Pasal 1 butir 14, pendidikan anak usia dini didefinisikan sebagai suatu upaya pembinaan yang ditujukan kepada anak sejak lahir sampai dengan usia enam tahun yang dilakukan melalui pemberian rangsangan pendidikan untuk membantu pertumbuhan dan perkembangan jasmani dan rohani agar anak memiliki kesiapan dalam memasuki pendidikan lebih lanjut.
Pendidikan anak usia dini merupakan salah satu bentuk penyelenggaraan pendidikan yang menitikberatkan pada peletakan dasar ke arah pertumbuhan dan perkembangan fisik (koordinasi motorik halus dan kasar), kecerdasan (daya pikir, daya cipta, kecerdasan emosi, kecerdasan spiritual), sosio emosional (sikap dan perilaku serta agama) bahasa dan komunikasi, sesuai dengan keunikan dan tahap-tahap perkembangan yang dilalui oleh anak usia dini.

Dengan demikian ada dua tujuan diselenggarakannya pendidikan anak usia dini, diantarnya adalah sebagai berikut:

1. Tujuan utama: untuk membentuk anak Indonesia yang berkualitas, yaitu anak yang tumbuh dan berkembang sesuai dengan tingkat perkembangannya sehingga memiliki kesiapan yang optimal di dalam memasuki pendidikan dasar serta mengarungi kehidupan di masa dewasa.

2. Tujuan penyerta: untuk membantu menyiapkan anak mencapai kesiapan belajar (akademik) di sekolah. Rentangan anak usia dini menurut Pasal 28 UU Sisdiknas No.20/2003 ayat 1 adalah 0-6 tahun. Sementara menurut kajian rumpun keilmuan PAUD dan penyelenggaraannya di beberapa negara, PAUD dilaksanakan sejak usia 0-8 tahun.

Berikut ini adalah ruang Lingkup Pendidikan Anak Usia Dini yang dapat dijadikan pedoman oleh lembaga penyelenggara adalah sebagai berikut:

a Infant (0-1 tahun)

b Toddler (2-3 tahun)

c. Preschool/ Kindergarten children (36 tahun) 
d. Early Primary School (SD Kelas Awal) (6-8 tahun)

Akan tetapi, ada hal-hal yang harus dan perlu dipahami oleh penyelenggara dalam hal Karakteristik Anak Usia Dini adalah sebagai berikut:

a. Mengetahui hal-hal yang dibutuhkan oleh anak, yang bermanfaat bagi perkembangan hidupnya.

b. Mengetahui tugas-tugas perkembangan anak, sehingga dapat memberikan stimulasi kepada anak, agar dapat melaksanakan tugas perkembangan dengan baik.

c. Mengetahui bagaimana membimbing proses belajar anak pada saat yang tepat sesuai dengan kebutuhannya.

d. Menaruh harapan dan tuntutan terhadap anak secara realistis.

e. Mampu mengembangkan potensi anak secara optimal sesuai dengan keadaan dan kemampuannya. fisik dan psikologis ( hall \& lindzey, 1993).

Adapun pentingnya pelayanan Pendidikan Anak Usia Dini (PAUD) adalah sebagai berikut:

a. PAUD sebagai titik sentral strategi pembangunan sumber daya manusia dan sangat fundamental.

b. PAUD memegang peranan penting dan menentukan bagi sejarah perkembangan anak selanjutnya, sebab merupakan fondasi dasar bagi kepribadian anak.

c. Anak yang mendapatkan pembinaan sejak dini akan dapat meningkatkan kesehatan dan kesejahteraan fisik maupun mental yang akan berdampak pada peningkatan prestasi belajar, etos kerja, produktivitas, pada akhirnya anak akan mampu lebih mandiri dan mengoptimalkan potensi yang dimilikinya.

d. Merupakan Masa Golden Age (Usia Keemasan). Dari perkembangan otak manusia, maka tahap perkembangan otak pada anak usia dini menempati posisi yang paling vital yakni mencapai $80 \%$ perkembangan otak.

e.Cerminan diri untuk melihat keberhasilan anak dimasa mendatang. Anak yang mendapatkan layanan baik semenjak usia 0-6 tahun memiliki harapan lebih besar untuk meraih keberhasilan di masa mendatang. Sebaliknya anak yang tidak mendapatkan pelayanan pendidikan yang memadai membutuhkan perjuangan yang cukup berat untuk mengembangkan hidup selanjutnya.

\section{Landasan Yuridis Tentang PAUD}

Pembukaan UUD 1945 menyatakan bahwa salah satu tujuan kemerdekaan adalah mencerdaskan kehidupan bangsa. Oleh karena itu amandemen UUD 1945 pada pasal 28 C"Setiap anak berhak mengembangkan diri melalui pemenuhan kebutuhan dasarnya, berhak mendapat pendidikan dan memperoleh manfaat dari ilmu pengetahuan dan teknologi, seni dan budaya demi meningkatkan kualitas hidupnya dan demi kesejahteraan umat manusia."

UU No. 23/2002 Tentang perlindungan anak Pasal 9 ayat (1) menyebutkan setiap anak berhak memperoleh pendidikan dan pengajaran dalam rangka pengembangan pribadinya dan tingkat kecerdasannya sesuai dengan minta dan bakat seperti: 
a. Pendidikan anak usia dini diselenggarakan sebelum jenjang pendidikan dasar.

b. Pendidikan anak usia dini dapat diselenggarakan melalui jalur pendidikan formal, non formal, dan/atau informal.

c. Pendidikan anak usia dini pada jalur pendidikan formal berbentuk Taman Kanak-Kanak (TK), Raudhatul Athfal (RA), atau bentuk lain yang sederajat.

d. Pendidikan anak usia dini pada jalur pendidikan non formal berbentuk kelompok bermain (KB), Taman Penitipan Anak (TPA), atau bentuk lain yang sederajat.

e. Pendidikan anak usia dini pada jalur informal berbentuk pendidikan keluarga atau pendidikan yang diselenggarakan oleh lingkungan.

\section{Perkembangan Anak}

Ditinjau dari ilmu psikologi perkembangan bahwa usia 6-8 tahun memang masih berada dalam rentang usia 08 tahun. Itu berarti pendidikan yang diberikan dalam keluarga maupun di lembaga pendidikan formal haruslah kental dengan nuansa pendidikan anak usia dini, yakni dengan mengutamakan konsep belajar sambil bermain. Perkembangan anak sebagai perubahan psikologis menurut Kartini Kartono ditunjang oleh faktor lingkungan dan proses belajar dalam fase tertentu.

Nana Syaodah Sukmadinata mengemukakan ada tiga pendekatan perkembangan individu, yaitu Pendekatan Pentahapan, diferensial dan isaptif. Khususnya pada pendekatan isaptif pada perkembangan anak mencakup perkembangan psikososial, perkembangan motorik, perkembangan kognitif, perkembangan sosial, perkembangan bahasa, perkembangan moral dan perkembangan emosional.

Tahapan perkembangan psikososial anak menurut Erik Erikson dalam Malcolm Knowles mengemukakan sebagai berikut:

a.Tahap kepercayaan dan ketidak percayaan (trust versus misstrust), yaitu tahap psikososial yang terjadi selama tahun pertama kehidupan. Pada tahap ini,bayi mengalami konflik anatara percaya dan tidak percaya. Rasa percaya menuntut perasaan nyaman secara fisik dan sejumlah kecil ketakutan serta kekhawatiran akan masa depan.

b.Tahap otonomi dengan rasa malu dan ragu (autonomi versus shame and doubt), yaitu tahap kedua perkembangan psikososial yang berlangsung pada akhir masa bayi dan masa baru pandai berjalan. Setelah memperoleh kepercayaan dari pengasuh mereka, bayi mulai menemukan bahwa perilaku mereka adalah milik mereka sendiri. Mereka mulai menyatakan rasa mandiri atau atonomi mereka dan menyadari kemauan mereka. Jika orangtua cenderung menuntut terlalu banyak atau terlalu membatasi anak untuk menyelidiki lingkungannya, maka anak akan mengalami rasa malu dan raguragu.

c.Tahap prakarsa dan rasa bersalah (initiatif versus guilt), yaitu tahap perkembangan psikososial ketiga yang berlangsung selama tahun pra sekolah. Pada tahap ini anak terlihat sangat aktif, suka berlari, berkelahi, memanjat-manjat, dan suka menantang lingkungannya. Dengan menggunakan bahasa, fantasi dan permainan khayalan, 
dia memperoleh perasaan harga diri. Bila orangtua berusaha memahami, menjawab pertanyaan anak, dan menerima keaktifan anak dalam bermain, maka anak akan belajar untuk mendekati apa yang diinginkan, dan perasaan inisiatif semakin kuat. Sebaliknya, bila orangtua kurang memahami, kurang sabar, suka memberi hukuman dan menganggap bahwa pengajuan pertanyaan, bermain dan kegiatan yang dilakukan anak tidak bermanfaat maka anak akan merasa bersalah dan menjadi enggan untuk mengambil inisiatif mendekati apa yang diinginkannya.

d.Tahap kerajinan dan rasa rendah diri (industry versus inferiority),yaitu perkembangan yang berada langsung kira-kira tahun sekolah dasar. Pada tahap ini, anak mulai memasuki dunia yang baru, yaitu sekolah dengan segala aturan dan tujuan. Anak mulai mengarahkan energi mereka menuju penguasaan pengetahuan dan keterampilan intelektual.perasaan anak akan timbul rendah diri apabila tidak bisa menguasai keterampilan yang diberikan disekolah.

e. Tahap identitas dan kekacauan identitas (identity versus identity confusion), yaitu perkembangan yang berlangsung selama tahuntahun masa remaja. Pada tahap ini, anak dihadapkan pada pencarian jati diri. Ia mulai merasakan suatu perasaan tentang identitasnya sendiri, perasaan bahwa ia adalah individu unik yang siap memasuki suatu peran yang berarti ditengah masyarakat baik peran yang bersifat menyesuaikan diri maupun memperbaharui. Apabila anak mengalami krisis dari masa anak kemasa remaja maka akan menimbulkan kekacauan identitas yang mengakibatkan perasaan anak yang hampa dan bimbang.

f.Tahap keintiman dan isolasi (intimacy versus isolation), yaitu perkembangan yang dialami pada masa dewasa. Pada masa ini adalah membentuk relasi intim dengan oranglain. Menurut erikson, keintiman tersebut biasanya menuntut perkembangan seksual yang mengarah pada hubungan seksual dengan lawan jenis yang dicintai. Bahaya dari tidak tercapainya selama tahap ini adalah isolasi, yakni kecenderungan menghindari berhubungan secara intim dengan oranglain kecuali dalam lingkup yang amat terbatas.

g.Tahap generativitas dan stagnasi (generativity versus stagnation), yaitu perkembangan yang dialami selama pertengahan masa dewasa. Ciri utama tahap generativitas adalah perhatian terhadap apa yang dihasilkan (keturunan, produk, ide-ide, dan sebagainya) serta pembentukan dan penetapan garis-garis pedoman untuk generasi mendatang. Apabila generativitas tidak diungkapkan dan lemah maka kepribadian akan mundul mengalami pemiskinan dan stagnasi.

h.Tahap integritas dan keputusasaan (integrity versus despair), yaitu perkembangan selama akhir masa dewasa. Integritas terjadi ketika seorang pada tahun-tahun terakhir kehidupannya

menoleh 
kebelakang dan mengevaluasi apa yang telah dilakukan dalam hidupnya selama ini, menerima dan menyesuaikan diri dengan keberhasilan dan kegagalan yang dialaminya, merasa aman dan tentram, serta menikmati hidup sebagai yang berharga dan layak. Akan tetapi, bagi orangtua yang dihantui perasaan bahwa hidupnya selama ini sama sekali tidak mempunyai makna ataupun memberikan kepuasan pada dirinya maka ia akan merasa putus asa.

Akan tetapi perkembangan kognitif anak usia dini Menurut PIAGET memiliki tahapan perkembangan sebagai berikut:

a. Sensori Motor (usia 0-2 tahun)

Dalam tahap ini perkembangan panca indra anak sangat berpengaruh dalam diri anak,sehingga perkembangan anak ada yang cepat, sedang, dan lambat dan orang tua dirumah harus memberi dorongan agar anak tiu dapat tumbuh dan berkemban secara sempurna. Dan keinginan terbesarnya adalah keinginan untuk menyentuh/memegang, karena didorong oleh keinginan untuk mengetahui reaksi dari perbuatannya.

Anak usia ini belum mengerti akan motivasi dan senjata terbesarnya adalah menangis atau merusaknya. Orang tua maupun guru menyampaikan cerita pada anak usia ini tidak dapat hanya sekedar dengan menggunakan gambar sebagai alat peraga, melainkan harus dengan sesuatu yang bergerak seperti misalnya permainan pada panggung boneka.

b. Pra-operasional (usia 2-7 tahun)

Pada usia ini anak menjadi egosentris, sehingga berkesan pelit, karena tidak bisa melihat dari sudut pandang orang lain. Anak tersebut juga memiliki kecenderungan untuk meniru orang yang ada di sekelilingnya. Meskipun pada saat berusia 6-7 tahun sudah mulai mengerti motivasi, namun tidak mengerti cara berpikir yang sistematis dan rumit. Dalam menyampaikan cerita harus ada alat peraga atau yang bias dilihat dan dirasakan oleh anak.

c. Operasional Kongkrit (usia 7-11 tahun)

Saat ini anak mulai meninggalkan rasa egosentrisnya dan dapat bermain dalam kelompok dengan aturan kelompok dan bekerja sama dengan kelompok lainnya. Anak sudah dapat dimotivasi dan mengerti hal-hal yang sistematis terutama karakter lingkungannya.

Anak sudah dapat menyesuaikan diri dengan apa yang dilihat maupun dirasakan, sehingga tidak banyak berontak yang penting dapat bermain dengan temannya. Dan biasanya akan menggunakan apa saja sebagai fasilitas bermain.

d. Operasional Formal (usia 11 tahun ke atas)

Pengajaran pada anak pra-remaja ini menjadi sedikit lebih mudah, karena sudah mengerti konsep dan dapat berpikir, baik secara konkrit maupun abstrak, sehingga tidak perlu menggunakan alat peraga, dan anak dapat secara langsung menggunakan apa yang dimainkan.

Namun kesulitan baru yang dihadapi guru adalah harus menyediakan waktu untuk dapat memahami pergumulan yang sedang mereka hadapi ketika memasuki usia pubertas.Pada umumnya dalam perkembangan Emosional seorang anak terdapat empat kunci utama emosi pada anak yaitu :

1. Perasaan marah

Perasaan ini akan muncul ketika anak terkadang merasa tidak nyaman dengan lingkungannya atau ada sesuatu yang 
mengganggunya. Kemarahan pun akan dikeluarkan anak ketika merasa lelah atau dalam keadaan sakit. Begitu punketika kemauannya tidak diturutioleh orangtuanya, terkadang timbulrasa marah pada sianak.

2. Perasaan takut

Rasa takut ini di rasakan anak semenjak bayi. Ketika bayi merekatakut akan suara-suara yang gaduh atau rebut. Ketika menginjak masa anak-anak, perasaan takut mereka muncul apabila di sekelilingnya gelap. Mereka pu mulai berfantasi dengan adanya hantu, monster dan mahluk-mahluk yang menyeramkan lainnya.

3. Perasaan gembira

Perasaan gembira ini tentu saja muncul ketika anak merasa senang akan sesuatu. Contohnya ketika anakdiberi hadiaholeh orang tuanya, ketika anak juara dalam mengikuti suatu lomba, atau ketika anak dapat melakukan apa yang diperintahkan orang tuanya. Banyak hal yang dapat membuat anak merasa gembira.

\section{Rasa humor}

Tertawa merupakan hal yang sangat universal. Anak lebih banyak tertawa di bandingkan orang dewasa. Biasanya anak akan tertawa ketika melihat sesuatu yang lucu.

Keempat perasaan itu merupakan emosi negative dan positif yang dimiliki oleh anak. Perasaan marah dan ketakutan merupakan sikap emosi yang negative sedangkan perasaan gembira dan rasa lucu atau humor merupakan sikap emosi yang positif.

Sementara itu menurut Kohlberg Perkembangan moral (moral development) berhubungan dengan peraturan-peraturan dan nilai-nilai mengenai apa yang harus dilakukan seseorang dalam interaksinya dengan orang lain. Anak-anak ketika dilahirkan tidak memiliki moral (imoral). Tetapi dalam dirinya terdapat potensi yang siap untuk dikembangkan. Karena itu, melalui pengalamannya berinteraksi dengan orang lain (dengan orang tua, saudara dan teman sebaya), anak belajar memahami tentang perilaku mana yang baik, yang boleh dikerjakan dan tingkah laku mana yang buruk, yang tidak boleh dikerjakan.

\section{Peranan keluarga.}

Keluarga adalah institusi pertama yang melakukan pendidikan dan pembinaan terhadap anak (generasi). Disanalah pertama kali dasar-dasar kepribadian anak dibangun dan dibimbing. Dan anak dibimbing bagaimana mengenal Penciptanya agar kelak anak itu hanya mengabdi kepada Ida Sanghyang Widhi Wasa sebagai pencipta. Demikian pula dengan pengajaran perilaku dan budi pekerti anak yang didapatkan dari sikap keseharian orangtua ketika bergaul dengannya. Bagaimana anak diajarkan untuk memilih kalimat-kalimat yang baik, sikap sopan santun, kasih sayang terhadap saudara dan orang lain.

Anak juga diajarkan untuk memilih cara yang benar ketika memenuhi kebutuhan hidup dan memilih barang hal-hal yang akan digunakan. Kesimpulannya, potensi dasar untuk membentuk generasi berkualitas dipersiapkan oleh keluarga.Keluarga dalam hal ini adalah aktor yang sangat menentukan terhadap masa depan perkembangan anak. Dari pihak keluarga perkembangan pendidikan sudah dimulai semenjak masih dalam kandungan. Anak yang belum lahir sebenarnya sudah bisa menangkap dan merespons apa-apa yang dikerjakan oleh orang tuanya, terutama kaum ibu.

Tidak heran kemudian apabila anak yang dibesarkan dalam situasi dan kondisi yang kurang membaik semasa masih dalam kandungan berpengaruh terhadap kecerdasan anak ketika lahir. Dengan demikian, pihak keluarga sejatinya banyak 
mengetahui perkembangan-perkembangan anak terutama di rumah. Pada saat anak masih dalam kandungan, pihak orang tua harus lebih memperbanyak perkataan, perbuatan, dan tindakan-tindakan yang lebih edukatif.

Ketika anak itu sudah lahir, maka tantangan terberat adalah bagaimana orang tua dapat mengasihi dan menyayangi anak sesuai dengan dunianya. Poin yang kedua ini ketika anak-anak (usia bayi hingga dua tahun) mempunyai tahap perkembangan yang cukup potensial. Anak-anak mempunyai imajinasi dengan dunianya yang bisa membuahkan kreativitas dan produktivitas pada masa depannya. Tetapi, pada fase-fase tertentu banyak orang tua tidak memberikan kebebasan untuk berekspresi, bermain, dan bertingkah laku sesuai dengan imajinasinya sehingga perilaku anak banyak yang menyimpang.

Pengekangan dan pengarahan menurut orang tua tidak baik untuk memompa kecerdasan dan kreativitas anak. Bahkan, malah dapat berakibat sebaliknya, yakni anak-anak akan kehilangan dunianya sehingga daya kreativitas anak dipasung dan dipaksa masuk dalam dunia orang tua seperti duplikat orang tuanya. Dan paradigma semacam ini yang sejatinya harus diubah oleh pihak orang tua dalam proses pendidikan anak usia dini.

Menarik salah satu pernyataan seorang pujangga Lebanon, Kahlil Gibran (1883) yang menyebutkan bahwa Anak kita bukanlah kita, pun bukan orang lain. Ia adalah ia. Dan hidup di zaman yang berbeda dengan kita. Karena itu, memerlukan sesuatu yang lain dengan yang kita butuhkan. Kita hanya boleh memberi ramburambu penentu jalan dan menemaninya ikut menyeberangi jalan. Kita bisa memberikan kasih sayang, tapi bukan pendirian. Dan sungguh pun mereka bersamamu, tapi bukan milikmu.
Pernyataan tersebut cukup tepat untuk mewakili siapa sebenarnya anak-anak itu dan bagaimana seharusnya berbuat yang terbaik untuknya dimasa depan. Untuk itu pernyataan di atas sejatinya dapat dijadikan referensi dalam memandang anak-anak oleh keluarga, terutama orang tua, yang ingin menjadikan anaknya berkembang secara kreatif, dinamis, dan produktif.Keluarga yang selama ini masih cenderung kaku dalam mendidik anaknya pada masa kecil sejatinya diubah pada pola yang lebih dinamis dan mendidik.

Anak sebenarnya sudah mempunyai dunianya tersendiri yang beda dengan orang dewasa. Hanya dengan kebebasan bukan pengerangkengan anak-anak akan tetai bisa memfungsikan keliaran dan kreativitasnya secara lebih produktif. Hanya dengan dunianya anak-anak akan mampu mengaktualisasikan segenap potensi yang ada dalam dirinya dan yang perlu disadari bahwa anak tiu adalah idividu yang sedang tumbuh dan berkembang.

Oleh karena itu besarnya peranan orang tua dalam perkembangan anak maka orang tua juga dituntut untuk dapat memahami pola-pola perkembangan anak sehingga dapat mengarahkan anak sesuai dengan masa perkembangan tersebut. Selanjutnya orangtua berkewajiban untuk menciptakan situasi dan kondisi yang memadai untuk menunjang perkembangan anak-anaknya.

Dengan tercapainya perkembangan anak kearah yang sempurna maka akan terciptanya keluarga yang sejahtera. Menurut Siregar dalm makalahnya 2 agustus 1996 pada seminar hari anak Indonesia di Bandung mengemukakan tentang keluarga sejahtera yaitu bahwa keluarga sejahtera selalu didambakan setiap individu.

Tujuan utama dari keluarga sejahtera adalah keluarga hendaknya merupakan wadah pengembangan anak seoptimal 
mungkin, sehingga dapat berkembang menjadi pribadi dewasa yang penuh tanggung jawab dan matang dikemudian hari.

\section{Menumbuhkan Kecerdasan Anak Usia Dini}

Seorang anak yang baru lahir, masih berada dalam keadaan lemah, naluri dan fungsi-fungsi fisik maupun psikisnya belum berkembang dengan sempurna. Namun secara pasti berangsur-angsur anak akan terus belajar dengan lingkungannya yang baru dan dengan alat inderanya, baik itu melalui pendengaran, penglihatan, penciuman, perabaan mapun pengecapan. Anak berkemungkinan besar untuk berkembang dan menyesuaikan diri dengan lingkungan sosialnya. Bahkan anak bisa meningkat pada taraf perkembangan tertinggi pada usia kedewasaannya sehingga ia mampu tampil sebagai pionir dalam mengendalikan alam sekitar. Hal ini karena anak memiliki potensi yang telah ada dalam dirinya.

Hal yang dibutuhkan anak agar tumbuh menjadi anak yang cerdas adalah adanya upaya-upaya pendidikan sepertiu terciptanya lingkungan belajar yang kondusif, memotivasi anak untuk belajar, dan bimbingan serta arahan kearah perkembangan yang optimal. Dengan begitu menumbuhkan kecerdasan anak yaitu mengaktualisasikan potensi yang ada dalam diri anak. Sebab jika potensi kecerdasannya tidak dibimbing dan diarahkan dengan rangsangan-rangsangan intelektual, maka walaupun dia memiliki bakat jenius aakan tidak ada artinya sama sekali. Sebaliknya jika seorang anak yang memiliki kecerdasan rata-rata atau normal bila didukung lingkungan yang kondusif maka ia akan dapat tumbuh menjadi anak yang cerdas diatas rata-rata atau superior. Hal ini berarti lingkungan memegang peranan penting bagi pendidikan anak selain bakat yang telah dimiliki oleh anak itu sendiri.

\section{Karakteristik Belajar Anak}

Menurut konsep pendidikan anak usia dini (PAUD) yang sebenarnya, anakanak seharusnya dikondisikan dalam suasana belajar aktif, kreatif, dan menyenangkan lewat berbagai permainan. Dengan demikian, kebutuhannya akan rasa aman dan nyaman tetap terpenuhi. Kalaupun kepada siswa SD kelas awal ingin diajarkan konsep berhitung, contohnya, pilihlah sarana pembelajaran melalui nyanyian atau cara lain yang mudah dipahami dan menyenangkan.

Hanya saja, meski sama-sama melalui cara yang menyenangkan, tujuan pendidikan anak usia prasekolah berbeda dari pendidikan anak usia sekolah dasar awal. Kalau pendidikan bagi anak usia prasekolah bertujuan mengoptimalkan tumbuh kembang anak, maka konsep pendidikan di awal sekolah dasar bertujuan mengarahkan anak agar dapat mengikuti tahapan-tahapan pendidikan sesuai jenjangnya.

Selain tentu saja untuk mengembangkan berbagai kemampuan, pengetahuan, dan keterampilan guna mengoptimalkan kecerdasannya.

Proses pembelajaran kepada anak harus sesuai dengan konsep pendidikan anak usia dini. Mengajarkan konsep membaca dan berhitung, contohnya, haruslah dengan cara yang menarik dan bisa dinikmati anak. Yang tidak kalah penting, selama proses belajar, jadikan anak sebagai pusatnya dan bukannya guru yang mendominasi kelas. Dalam pelaksanaannya, inilah yang disebut CBSA (Cara Belajar Siswa Aktif). Jadi bukannya "CBSA" yang kerap diplesetkan sebagai "Catat Buku Sampai Abis". 
Sementara pendidikan usia dini yang diberikan dalam keluarga juga harus berpijak pada konsep PAUD. Artinya, pola asuh yang diterapkan orang tua hendaknya cukup memberi kebebasan kepada anak untuk mengembangkan aneka keterampilan dan kemandiriannya. Ingat, porsi waktu terbesar yang dimiliki anak adalah bersama keluarganya dan bukan di sekolah.

\section{Program Pendidikan Bagi Anak Usia Dini}

Peraturan Pemerintah Nomor 27 tahun 1992 tentang pendidikan pra-sekolah, pasal 4 ayat (1) disebutkan bahwa "bentuk satuan pendidikan pra-sekolah meliputi Taman Kanak-kanak, Kelompok Bermain dan Penitipan Anak serta bentuk lain yang diterapkan oleh Menteri.

Kelompok Bermain

Pendidikan dini bagi anak-anak usia pra-sekolah (3-6 tahun) merupakan hal yang penting, karena pada usia ini merupakan masa membentuk dasar-dasar kepribadian manusia, kemampuan berfikir, kecerdasan, keterampilan serta kemandirian maupun kemampuan bersosialisasi. Pada dasarnya dunia anak adalah dunia fundamental dari perkembangan manusia menuju manusia dewasa yang sempurna. Disadari bahwa generasi merupakan generasi penerus yang perlu dibina sejak dini, karenanya pembinaan sejak dini merupakan tanggung jawab keluarga dan masyarakat. Pembinaan anak usia pra-sekolah terutama peranan keluarga sangat menentukan.

Menurut Peraturan Pemerintah No 27 tahun 1990 tentang pendidikan pra-sekolah, Kelompok Bermain adalah salah satu bentuk usaha kesejahteraan anak dengan mengutamakan kegiatan bermain, yang juga menyelenggarakan pendidikan pra-sekolah bagi anak usia 3 tahun sampai memasuki pendidikan dasar.
Selama tahun pra-sekolah, taman kanak-kanak, pusat penitipan anak-anak dan kelompok bermain semuanya menekankan permainan yang memakai mainan. Akibatnya baik sendiri atau berkelompok mainan merupakan unsure yang penting dari aktivitas bermain anak. Bermain dengan teman-teman sebayanya, anak dirangsang dalam kemampuan mental seperti kecerdasan, kreativitas, kemampuan sosial yang sangat bermanfaat pada masa kini dan masa yang akan datang. Kegiatan bermain memiliki arti positif terhadap perkembangan sosial anak. Seperti yang dikemukakan oleh Zulkifli bahwa dengan berman mereka lebih banyak mengenal benda-benda yang berguna bagi perkembangan sosialnya. Hal ini dapat terlihat dengan mengenal benda seperti mobil dapat mengembangkan rasa sosial anak dimana benda tersebut dapat membantu orang lain eprgi kesuatu tempat tertentu. Secara lebih jauh dapat dilihat dengan adanya perkembangan teknologi menunjukan makin menariknya teknis dan permainan elektronik bagi anak yang ditunjang oleh situasi dan kondisi dimana anak-anak sulit mendapat teman sebaya untuk bersosialisasi sehingga anak dapat menonton atau bermain sendiri tanpa memerlukan oranglain.

\section{PENUTUP KESIMPULAN}

1.Seorang anak yang baru lahir, ia masih berada dalam keadaan lemah, naluri dan fungsi-fungsi fisik maupun psikisnya belum berkembang dengan sempurna. Dan perlu dibantu oleh orang tua di rumah, guru di sekolah dan lingkungan dimana anak itu berada.

2.Anak agar tumbuh menjadi anak yang cerdas adalah adanya upaya-upaya pendidikan sepertiu terciptanya lingkungan 
belajar yang kondusif, memotivasi anak untuk belajar, dan bimbingan serta arahan kearah perkembangan yang optimal. Dengan begitu menumbuhkan kecerdasan anak yaitu mengaktualisasikan potensi yang ada dalam diri anak.

3.Masa usia dini merupakan Periode emas yang merupakan periode kritis bagi anak, dimana perkembangan yang diperoleh pada periode ini sangat berpengaruh terhadap perkembangan periode berikutnya hingga masa dewasa.

4.Sementara masa emas ini hanya datang sekali, sehingga apabila terlewat berarti habislah peluangnya. Untuk itu pendidikan untuk usia dini dalam bentuk pemberian rangsangan-rangsangan (stimulasi) dari lingkungan terdekat sangat diperlukan untuk mengoptimalkan kemampuan anak.

5.Pendidikan anak usia dini merupakan salah satu bentuk penyelenggaraan pendidikan yang menitikberatkan pada peletakan dasar ke arah pertumbuhan dan perkembangan fisik (koordinasi motorik halus dan kasar), kecerdasan (daya pikir, daya cipta, kecerdasan emosi, kecerdasan spiritual), sosio emosional (sikap dan perilaku serta agama) bahasa dan komunikasi, sesuai dengan keunikan dan tahap-tahap perkembangan yang dilalui oleh anak usia dini.

6.Konsep psikologi perkembangan, bahwa anak usia 6-8 tahun memang masih berada dalam rentang usia 0-8 tahun dan berada dibawah pengawasan orang tua dan guru. Itu berarti pendidikan yang diberikan dalam keluarga maupun di lembaga pendidikan formal haruslah kental dengan nuansa pendidikan anak usia dini, yakni dengan mengutamakan konsep belajar melalui bermain.

\section{DAFTAR PUSTAKA}

1. Ali Maskun,2003. Paradigma Pendidikan Universal. Nagoroya. Jogjakarta

2. M. Taqiyuddin. (2005). Pendidikan Untuk semua (Dasar dan Falsafah Pendidikan Luar Sekolah). Cirebon: STAIN Cirebon Press.

3. Purwanto. Ngalim. (2006). Ilmu pendidikan teoretis dan praktis. Bandung: Rosda

4. Gunawan, Ari. (1995). Kebijakankebijakan Pendidikan. Jakarta: PT. Rhineka Cipta

5. Latif, Abdul. (2007). Pendidikan Berbasis Nilai Kemasyarakatan. Bandung: Reflika Aditama

6. Nurihsan, Juntika, 2007. Perkembangan Peserta Didik, Bandung : Sekolah Pasca Sarjana UPI

7. PP NO.27 Tahun 1990

8. PP NO 27 Tahun 1992

9. UU NO. 20 Tahun 2003.

10. Surahmand.W.2009. Pendidikan Nasional. Kompas Media. Jakarta

11. Tilaar. (1992). Manajemen Pendidikan Nasional. Bandung: Rosda

12. Tanu, 2011. Konsep dan Makna Pembelajaran Era Global. Sari Kahyangan Denpasar. 